\title{
Impacts of inclusion of column feeder rohu (Labeo rohita) at different stocking densities on growth, production and environment in freshwater prawn-carp-mola polyculture system
}

\author{
M.E. Ahsan ${ }^{1 *}$, Wahab, M.A. ${ }^{2}$, M.A.B. Siddik ${ }^{3}$, M.A. Alam ${ }^{3}$, M.R. Sharker ${ }^{3}$ and A. Nahar ${ }^{1}$ \\ ${ }^{I}$ Dept. of Marine Fisheries and Oceanography, Patuakhali Science and Technology University, Patuakhali, Bangladesh \\ ${ }^{2}$ Dept. of Fisheries Management, Bangladesh Agricultural University, Mymensingh, Bangladesh \\ ${ }^{3}$ Dept. of Fisheries Biology and Genetics, Patuakhali Science and Technology University, Patuakhali, Bangladesh \\ *Corresponding author E-mail: meahsan.pstu@pstu.ac.bd
}

\begin{abstract}
The research investigated the impacts of inclusion of column feeder rohu (Labeo rohita) on growth and production in freshwater prawn-carp-mola polyculture system for a period of 172 days. Four stocking densities of Rohu were maintained as 500, 1,000, 1,500 and 2,000 ha ${ }^{-1}$ in treatment $R_{500}, R_{1000}, R_{1500}$ and $R_{2000}$, respectively in triplicates. All ponds each $120 \mathrm{~m}^{2}$ were stocked with juvenile freshwater prawn (Macrobrachium rosenbergii), silver carp (Hypophthalmichthys molitrix), catla (Catla catla) and small fish mola (Amblypharyngodon mola) at the fixed stocking densities of 20,000, 1,500, 1,000 and 20,000 ha ${ }^{-1}$, respectively. Prawns were fed with pelleted feed twice daily started with $10 \%$ and gradually reduced to $3 \%$ of body weight and continued throughout the study period. All fish were fed with mixture of soaked rice bran and mustard oilcake (2:1) at the rate of $3 \%$ of the body weight daily. All the water quality parameters and chlorophyll-a were measured. The density of rohu significantly $(\mathrm{P}<0.05)$ influenced the survival rate, growth and production of freshwater prawn. Catla and Mola production were affected adversely with increasing rohu density. The production of rohu increased with increasing density although the individual weight decreased. The combined production of all finfish was significantly lower in $\mathrm{R}_{0}$ whereas, the combined production of all species including prawn did not differ significantly $(\mathrm{P}<0.05)$ among the treatments. The treatments $\mathrm{R}_{0}$ and $\mathrm{R}_{500}$ fetched higher net profit without significant difference between them. Therefore, inclusion of rohu at a density of $500 \mathrm{ha}^{-1}$ may be recommended for prawn-carp-mola polyculture.
\end{abstract}

Keywords: Rohu (Labeo rohita), growth, production, prawn-carp-mola polyculture.

\section{Introduction}

Polyculture of prawn with finfish has the potential of increasing total yield as well as income, particularly as prawns have higher commercial value than most finfish (Zimmerman and New, 2000). In Bangladesh, several species, usually 5-7 of large carps are stocked in the polyculture systems. Both native and exotic species are stocked together, many of them have been found antagonistic to each other (Wahab and Ahmed, 1991). Prawns are omnivorous (Ling, 1969) and eat algae, aquatic plants, mollusks, aquatic insects, worms and other crustaceans. Cohen and Ra'anan (1983) have classified prawn as a benthopelagic omnivore. Silver carp is an important candidate species in the polyculture systems in Bangladesh (Wahab et al., 1995). Catla is the fastest growing fish among the three Indian major carps and a suitable species for polyculture. Rohu (Labeo rohita) is a herbivorous carp fish of family cyprinidae. Mola, Amblypharyngodon mola, is rich in micronutrients and vitamin-A content (Thilsted et al., 1997) and easily be consumed as food fish by the farmers for their family nutrition. Mola is particularly important as the fish contains more available vitamin A than any other edible fish species in this country (Ahmed 1981). Zafri and Ahmed (1981) reported that mola contains 200 IU of vitamin A per gram of edible protein. A medium size mola fish contains about $2.0 \mathrm{~g}$ edible protein in its muscles, which contain $400 \mathrm{IU}$ of vitamin A. This means that four mola if eaten daily may provide more than $1500 \mathrm{IU}$ of vitamin A, sufficient to save a child from night blindness caused by shortage of vitamin A. Development of appropriate culture technologies is one of the most important issues in Bangladesh to contribute to the national economy and to improve the standard of living of people through production of freshwater prawn along with high valued carps and nutrient rich small fish. To address this issue present study was designed to investigate the impacts of inclusion of column feeder 
rohu, Labeo rohita, an important major carp on growth and production and pond ecosystem in prawn-carp-mola polyculture system.

\section{Materials and methods}

The experiment was carried out for a period of six months from 15 June and 3 December, 2009 at the Department of Fisheries Management, Bangladesh Agricultural University, Mymensingh. Fifteen earthen ponds with an area of $120 \mathrm{~m}^{2}$ each and an average depth of $1 \mathrm{~m}$ were used for this study. Four treatments named as $\mathrm{R}_{500}, \mathrm{R}_{1000}, \mathrm{R}_{1500}$ and $\mathrm{R}_{2000}$ with inclusion of rohu at different stocking densities $\left(500,1,000,1,500\right.$ and 2,000 ha ${ }^{-1}$, respectively) were compared with a control devoid of rohu $\left(\mathrm{R}_{0}\right)$ each with three replications. All ponds were stocked with juvenile freshwater prawn (Macrobrachium rosenbergii), silver carp (Hypophthalmichthys molitrix), catla (Catla catla) and small fish mola (Amblypharyngodon mola) at the fixed stocking densities of 20,000, 1,500, 1,000 and 20,000 ha ${ }^{-1}$, respectively as well. All ponds were drained out and prepared by removing weeds, predators and other fishes from the ponds. Afterwards, the ponds were treated with agricultural lime @ $2.5 \mathrm{~kg} /$ pond $\left(250 \mathrm{~kg} \mathrm{ha}^{-1}\right)$. To promote algal growth ponds were fertilized with organic and inorganic fertilizers. Urea, TSP (Triple Super Phosphate) and cowdung were applied @ $250 \mathrm{~g}, 250 \mathrm{~g}$ and $7.5 \mathrm{~kg} /$ pond $(750 \mathrm{~kg} / \mathrm{ha})$ respectively. Fresh water prawns were fed with pellets (28\% crude protein) daily at a rate of $10 \%$ for first month, $8 \%$ for the second month, $6 \%$ for the third month and $3 \%$ for rest of the culture period. Half of the daily feed was applied in the morning and rest half in the evening. Rohu were fed with mixture of rice bran and mustard oilcake $(2: 1)$ at the rate of $3 \%$ of the body weight daily. All ponds were fertilized with organic (cow manure) and inorganic fertilizer (urea and TSP) in each 15 days interval. A number of water quality parameters such as temperature $\left({ }^{\circ} \mathrm{C}\right)$, transparency $(\mathrm{cm}), \mathrm{pH}$ and dissolved oxygen $(\mathrm{mg} / \mathrm{l})$ were recorded weekly using a commercial kit box (Model: FF-3, USA). Total alkalinity, $\mathrm{NH}_{3}-\mathrm{N}, \mathrm{NO}_{2}-\mathrm{N}, \mathrm{NO}_{3}-\mathrm{N}, \mathrm{PO}_{4}-\mathrm{P}$, and chlorophyll-a were monitored fortnightly by using HACH kit (DR 2010). Fish were sampled monthly by using a seine net. Weight of 10 fishes of each species was measured separately to assess the health condition and growth of fishes using a portable balance (OHAUS, model No.CT-1200-S). Final harvesting was done by de-watering the ponds. During harvesting all fishes of each pond were collected and weighed individually to assess the survival rate and production.

Specific growth rate (SGR) was estimated as;

SGR = [Ln (final weight)-Ln (initial weight) $x$ 100]/ culture period (days).

For the statistical analysis of the data, a one-way ANOVA (Analysis of Variance) and Tucky's test were done by using the SPSS (version-12.0) and the significance was assigned at 5\% level.

\section{Results}

\subsection{Water quality parameters}

Temperature, transparency, pH and Dissolved oxygen (DO) concentration of pond water, measured weekly throughout the experimental period, were found almost identical in all treatments in every sampling dates without showing significant difference $(\mathrm{P}>0.05)$ among the treatments (Table 1). Water transparency in terms of Secchi disk readings ranged within 25 and $46 \mathrm{~cm}$. Temperature of pond water was found to be more or less similar in different treatments. Water temperature ranged from $28-32^{\circ} \mathrm{C}$. Water $\mathrm{pH}$ ranged within 6.4 and 8.7. Dissolved oxygen concentration ranged within 4.65 and $5.89 \mathrm{mg} \mathrm{l}^{-1}$.

Table 1: Mean $( \pm \mathrm{SD})$ of Water quality parameters as obtained under 5 treatments.

\begin{tabular}{|c|c|c|c|c|c|c|c|}
\hline \multirow[t]{2}{*}{ Parameters } & \multicolumn{5}{|c|}{ Treatments } & \multirow[t]{2}{*}{ F value } & \multirow{2}{*}{$\begin{array}{c}\text { Level of } \\
\text { significance }\end{array}$} \\
\hline & $\mathrm{R}_{0}$ & $\mathrm{R}_{500}$ & $\mathrm{R}_{1000}$ & $\mathrm{R}_{1500}$ & $\mathrm{R}_{2000}$ & & \\
\hline Transparency $(\mathrm{cm})$ & $\begin{array}{c}34.52 \pm \\
5.84\end{array}$ & $\begin{array}{l}34.53 \pm \\
5.95\end{array}$ & $\begin{array}{l}34.47 \pm \\
6.43\end{array}$ & $\begin{array}{c}36.20 \pm \\
5.32\end{array}$ & $\begin{array}{l}36.13 \pm \\
5.84\end{array}$ & 1.435 & NS \\
\hline Temperature $\left({ }^{\circ} \mathrm{C}\right)$ & $\begin{array}{c}30.23 \pm \\
0.91\end{array}$ & $\begin{array}{c}30.25 \pm \\
0.92\end{array}$ & $\begin{array}{c}30.21 \pm \\
0.94\end{array}$ & $\begin{array}{c}30.15 \pm \\
0.89\end{array}$ & $\begin{array}{c}30.17 \pm \\
0.89\end{array}$ & 0.134 & NS \\
\hline $\begin{array}{l}\text { Total Alkalinity (mg } \\
\qquad \mathrm{l}^{-1} \text { ) }\end{array}$ & $\begin{array}{l}59.33 \pm \\
15.24^{\mathrm{ab}}\end{array}$ & $\begin{array}{l}65.50 \pm \\
13.94^{\mathrm{a}}\end{array}$ & $\begin{array}{l}65.70 \pm \\
18.36^{\mathrm{a}}\end{array}$ & $\begin{array}{l}53.70 \pm \\
13.56^{\mathrm{b}}\end{array}$ & $\begin{array}{l}61.13 \pm \\
13.61^{\mathrm{ab}}\end{array}$ & 3.257 & $*$ \\
\hline $\mathrm{pH}$ & $\begin{array}{c}7.23 \pm \\
0.41\end{array}$ & $\begin{array}{c}7.17 \pm \\
0.37\end{array}$ & $\begin{array}{c}7.17 \pm \\
0.40\end{array}$ & $7.09 \pm 0.54$ & $7.13 \pm 0.34$ & 0.949 & NS \\
\hline $\begin{array}{l}\text { Dissolved Oxygen } \\
\left(\mathrm{mg} \mathrm{l}^{-1}\right)\end{array}$ & $\begin{array}{c}5.34 \pm \\
0.57\end{array}$ & $\begin{array}{c}5.36 \pm \\
0.53\end{array}$ & $\begin{array}{c}5.36 \pm \\
0.52\end{array}$ & $\begin{array}{c}5.38 \pm \\
0.52\end{array}$ & $\begin{array}{c}5.35 \pm \\
0.48\end{array}$ & 1.435 & NS \\
\hline
\end{tabular}


Means with the different superscripts in same row are significantly different $(\mathrm{P}<0.05)$.

Total alkalinity of water was found to be ranged from 38 to $104 \mathrm{mgl}^{-1}$ and there was no significant difference (P>0.05) among treatment $\mathrm{R}_{0}, \mathrm{R}_{500}, \mathrm{R}_{1000}, \mathrm{R}_{1500}$ and $\mathrm{R}_{2000}$ but significant difference was observed in treatment $\mathrm{R}_{500}$ with treatment $\mathrm{R}_{1500}$ (Table 1). There were no treatment effects ( $\left.\mathrm{P}>0.05\right)$ on overall mean concentrations of inorganic nutrients (nitrate, nitrite and phosphate, except ammonia) but significant effects $(\mathrm{P}<0.05)$ of different sampling dates (time effects) on those were observed (Fig.1).
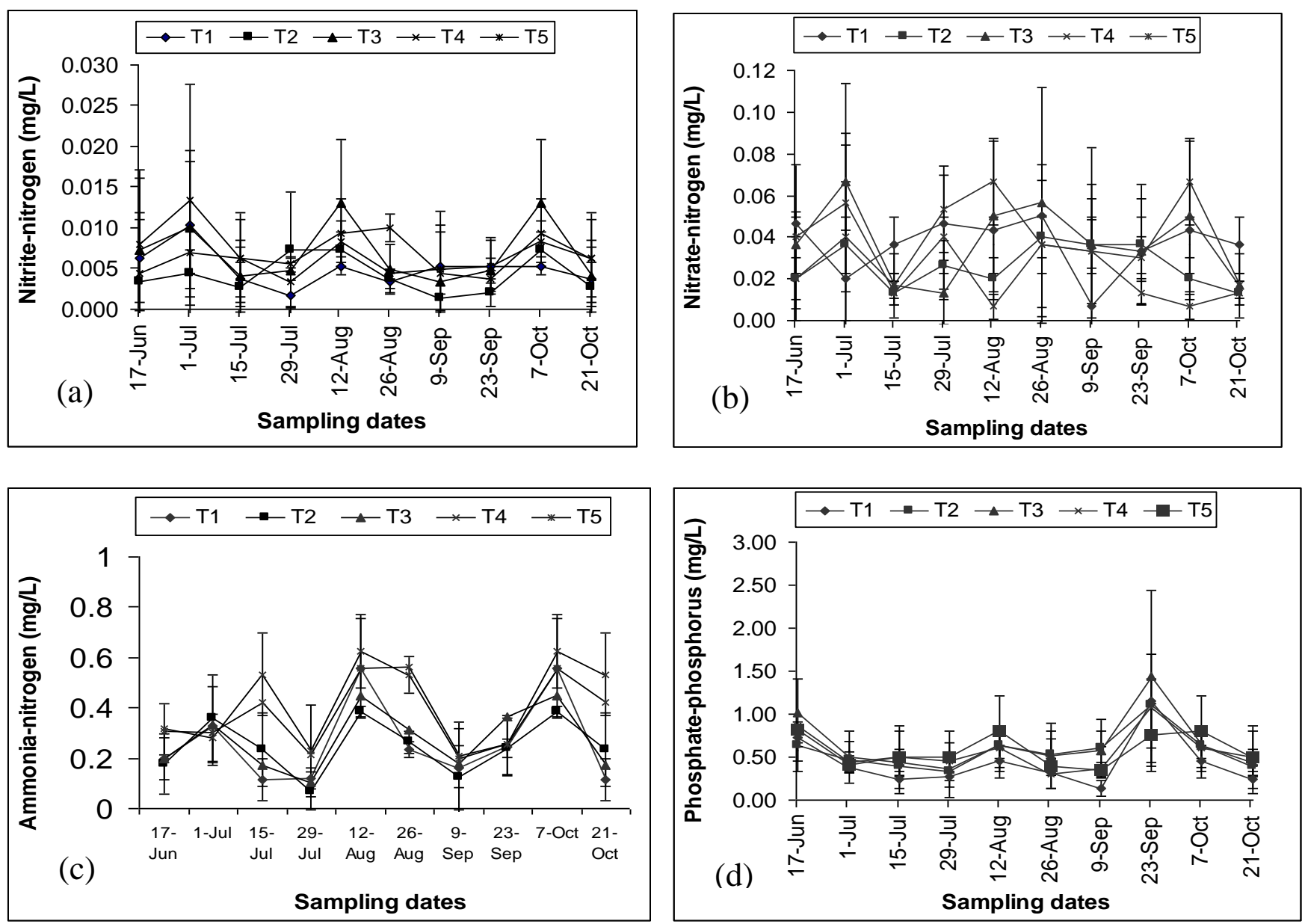

Fig. 1: Concentrations of (a), nitrite (b) nitrate, (c) ammonia, and (d) phosphate in different treatments. Values are means ( \pm SD) at bi-weekly sampling dates throughout the experimental period.

\subsection{Growth and production performance of fish:}

Growth and production of prawn and fish were varied from treatment to treatment. Gross and net production of prawn $\left(553 \mathrm{~kg}\right.$ and $534 \mathrm{~kg} \mathrm{ha}^{-1}$, respectively) was significantly higher $(\mathrm{P}<0.05)$ in control i.e. in absence of rohu $\left(\mathrm{R}_{0}\right)(\mathrm{Table} 2)$. Prawn production decreased gradually with increased rohu density. Silver carps growth and production did not vary significantly $(\mathrm{P}>0.05)$ among treatments regardless of rohu density. The gross production of silver carp ranged from $789 \mathrm{~kg}$ to $879 \mathrm{~kg} \mathrm{ha}^{-1}$. Catla performed higher gross production $\left(287 \mathrm{~kg} \mathrm{ha}^{-1}\right)$ in $\mathrm{R}_{0}$ and lower in $\mathrm{R}_{2000}\left(184 \mathrm{~kg} \mathrm{ha}^{-1}\right)$. Gross production of mola ranged from $86 \mathrm{~kg}$ to $105 \mathrm{~kg} \mathrm{ha}^{-1}$ (Table 2).

\subsection{Performance of fresh water prawn:}

The growth performances of fresh water prawn in all treatments are shown in Table 2. The yields of prawn were significantly different among the treatments $(P<0.05)$. The highest yield of prawn was resulted in treatment $R_{0}(534 \pm 4$ $\left.\mathrm{kg} \mathrm{ha}^{-1}\right)$ and the lowest yield was resulted in treatment $\mathrm{R}_{2000}\left(368 \pm 4 \mathrm{~kg} \mathrm{ha}^{-1}\right)$. Survival rate, mean weight at harvest and net production were significantly different among the treatments $(\mathrm{P}<0.05)$. The net production of prawn in different treatments was significantly different $(\mathrm{P}<0.05)$. There was a strong negative relation $\left(\mathrm{R}^{2}=0.943\right)$ between rohu density and prawn production (Fig. 2). 


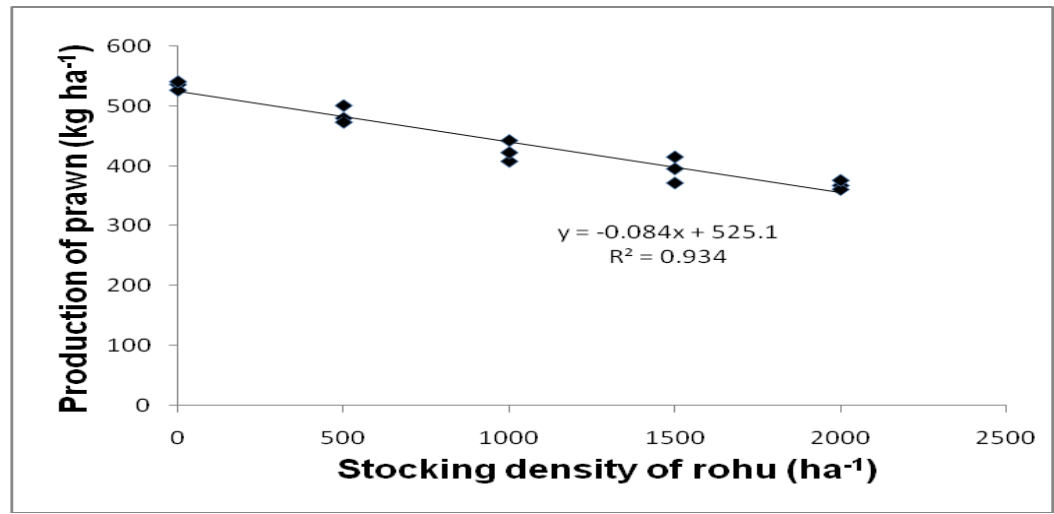

Fig. 2: Relation between rohu stocking density and prawn production

\subsection{Performance of rohu:}

The stocking density of rohu $\left(0,500,1000,1500\right.$ and $\left.2000 \mathrm{ha}^{-1}\right)$ in different treatments was the variable in the study. The highest yield of rohu $353 \pm 17 \mathrm{~kg} \mathrm{ha}^{-1}$ was observed in treatment $R_{2000}$ due to highest stocking density of rohu. The lowest yield was observed in treatment $R_{500}\left(175 \pm 8 \mathrm{~kg} \mathrm{ha}^{-1}\right)$. Individual growth performance of rohu was better in $R_{500}$ $\left(185 \mathrm{~kg} \mathrm{ha}^{-1}\right)$ whereas, higher gross and net productions of this fish were resulted in the treatment $\mathrm{R}_{2000}\left(353 \mathrm{~kg} \mathrm{ha}^{-1}\right)$ where stocking density of the species was higher. The yields were significantly different among treatments $(\mathrm{P}<0.05)$.

\subsection{Performance of catla:}

Catla reached an average weight of $305.2 \pm 17 \mathrm{~g}$ in treatment $\mathrm{R}_{0}, 286.3 \pm 12 \mathrm{~g}$ in treatment $\mathrm{R}_{500}, 249.6 \pm 14.4 \mathrm{~g}$ in treatment $\mathrm{R}_{1000}, 265.9 \pm 9.7 \mathrm{~g}$ in treatment $\mathrm{R}_{1500}$ and $214.4 \pm 16.1$ in treatment $\mathrm{R}_{2000}$. Mean harvesting weight, SGR (Specific Growth Rate) and net production were significantly different $(\mathrm{P}<0.05)$ among different treatments (Table 2$)$.

\subsection{Performance of silver carp:}

The highest growth of silver carp was recorded in treatment $R_{0}$ and lowest growth was recorded in treatment $R_{2000}$. Mean harvesting weight, SGR and net production were not significantly different $(\mathrm{P}<0.05)$ among the treatments. The growth performance of Silver carp in all treatments is shown in Table 2.

\subsection{Performance of mola:}

The small indigenous fish species, mola was stocked at a rate of 20,000 ha ${ }^{-1}$. Mola bred in July in all ponds and larger mola were then harvested partially with 15 days intervals. Mola production differed significantly $(\mathrm{P}<0.05)$ among the treatments with lower production in treatment $\mathrm{R}_{2000}$ (Table 2).

\subsection{Combined production:}

The combined net production of all species (prawn, carps and mola) did not vary among the treatments. The net production of all species were $1726 \mathrm{~kg} \mathrm{ha}^{-1}, 1783 \mathrm{~kg} \mathrm{ha}^{-1}, 1803 \mathrm{~kg} \mathrm{ha}^{-1}, 1790 \mathrm{~kg} \mathrm{ha}^{-1}$ and $1700 \mathrm{~kg} \mathrm{ha}^{-1}$ in 172 days culture period in treatment $R_{0}, R_{500}, R_{1000}, R_{1500}$ and $R_{2000}$ respectively. The combined production figures in all treatments are shown in Table 2.

\subsection{Economics of different treatments:}

Economic analysis was performed to estimate the net profit derived from the experiment. Total cost of the experiment was Tk. 1,84,049, 1,93,664, 1,98,356, 2,03,979 and 2,08,834 (Tk./ha/172days) in treatment $R_{0}, R_{500}, R_{1000}, R_{1500}$ and $R_{2000}$, respectively. The highest net profit of Tk. $1,20,359 \mathrm{ha}^{-1} 172 \mathrm{~d}^{-1}$ was achieved with treatment $\mathrm{R}_{0}$ and the lowest Tk. $50,068 \mathrm{ha}^{-1} 172 \mathrm{~d}^{-1}$ with treatment $\mathrm{R}_{2000}$. Net profit derived from different treatments is shown in Table 2. 
Table 2: Growth, survival, production and profit derived from different treatments

\begin{tabular}{|c|c|c|c|c|c|c|c|}
\hline \multirow{2}{*}{ 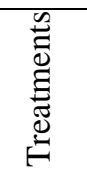 } & \multicolumn{3}{|c|}{ Fish stocked } & Fish harvested & \multicolumn{2}{|c|}{ Yield kg/ha/176 days } & \multirow[b]{2}{*}{$\begin{array}{r}\text { Net profit } \\
\quad(\text { BDT) }\end{array}$} \\
\hline & $\begin{array}{r}\text { Name of } \\
\text { Species }\end{array}$ & $\begin{array}{l}\text { Mean } \\
\text { wt }(g)\end{array}$ & $\begin{array}{r}\text { Mean final } \\
\text { wt }(\mathrm{g})\end{array}$ & $\begin{array}{r}\text { Survival } \\
(\%)\end{array}$ & $\begin{array}{r}\text { Species } \\
\text { wise }\end{array}$ & $\begin{array}{r}\text { Net } \\
\text { production } \\
\text { of all fish }\end{array}$ & \\
\hline \multirow{5}{*}{$\mathrm{R}_{0}$} & Prawn & $0.94 \pm 0.04$ & $43.4 \pm 0.4$ & $63.6 \pm 1.1^{\mathrm{a}}$ & $534 \pm 4^{\mathrm{a}}$ & \multirow{5}{*}{$1726 \pm 32$} & \multirow{5}{*}{$120359 \pm 7094^{2}$} \\
\hline & Rui & - & - & - & - & & \\
\hline & Catla & $20.4 \pm 0.1$ & $305.2 \pm 17^{\mathrm{a}}$ & $94.4 \pm 2.8$ & $267 \pm 8^{\mathrm{a}}$ & & \\
\hline & Silver carp & $22.4 \pm 0.3$ & $608 \pm 8$ & $96.3 \pm 1.8$ & $845 \pm 28$ & & \\
\hline & Mola & $1.25 \pm 0.03$ & - & - & $80 \pm 4 a$ & & \\
\hline \multirow{5}{*}{$\mathrm{R}_{500}$} & Prawn & $0.96 \pm 0.02$ & $42.9 \pm 0.3^{\mathrm{a}}$ & $58.6 \pm 1.0^{\mathrm{a}}$ & $484 \pm 8^{\mathrm{a}}$ & \multirow{5}{*}{$1783 \pm 39$} & \multirow{5}{*}{$103183 \pm 9834^{\circ}$} \\
\hline & Rui & $20.2 \pm 0.2$ & $392.4 \pm 7.9^{\mathrm{a}}$ & $94.4 \pm 5.6$ & $175 \pm 8^{c}$ & & \\
\hline & Catla & $20.2 \pm 0.2$ & $286.3 \pm 12.1^{\mathrm{a}}$ & $88.9 \pm 2.8$ & $235 \pm 18^{\mathrm{ab}}$ & & \\
\hline & Silver carp & $22.5 \pm 0.1$ & $568 \pm 18$ & $96.3 \pm 1.8$ & $812 \pm 21$ & & \\
\hline & Mola & $1.26 \pm 0.01$ & - & - & $78 \pm 1^{\mathrm{a}}$ & & \\
\hline \multirow{5}{*}{$\mathrm{R}_{1000}$} & Prawn & $0.92 \pm 0.02$ & $40.4 \pm 0.5^{\mathrm{a}}$ & $54.7 \pm 0.8^{\mathrm{bc}}$ & $424 \pm 10^{c}$ & \multirow{5}{*}{$1803 \pm 33$} & \multirow{5}{*}{$82510 \pm 8587^{\mathrm{b}}$} \\
\hline & Rui & $20.0 \pm 0.3$ & $319.4 \pm 19.9^{b}$ & $91.7 \pm 4.8$ & $271 \pm 9^{b}$ & & \\
\hline & Catla & $20.4 \pm 0.1$ & $249.6 \pm 14.4^{\mathrm{ab}}$ & $88.9 \pm 2.8$ & $201 \pm 5^{b c}$ & & \\
\hline & Silver carp & $22.7 \pm 0.2$ & $601 \pm 14$ & $96.3 \pm 1.8$ & $834 \pm 23$ & & \\
\hline & Mola & $1.28 \pm 0.04$ & - & - & $75 \pm 2^{\mathrm{a}}$ & & \\
\hline \multirow{5}{*}{$\mathrm{R}_{1500}$} & Prawn & $0.96 \pm 0.01$ & $39.8 \pm 0.42^{\mathrm{b}}$ & $51.8 \pm 1.6^{\mathrm{cd}}$ & $394 \pm 13^{\mathrm{cd}}$ & \multirow{5}{*}{$1790 \pm 34$} & \multirow{5}{*}{$69170 \pm 7579^{\mathrm{bc}}$} \\
\hline & Rui & $20.0 \pm 0.1$ & $268.3 \pm 7.7^{\mathrm{c}}$ & $87.0 \pm 1.8$ & $321 \pm 17^{\mathrm{ab}}$ & & \\
\hline & Catla & $20.5 \pm 0.2$ & $265.9 \pm 9.7^{\mathrm{ab}}$ & $88.9 \pm 2.8$ & $208 \pm 3^{b c}$ & & \\
\hline & Silver carp & $22.8 \pm 0.2$ & $598 \pm 7$ & $92.6 \pm 1.8$ & $797 \pm 25$ & & \\
\hline & Mola & $1.28 \pm 0.03$ & - & - & $71 \pm 2^{a b}$ & & \\
\hline \multirow{5}{*}{$\mathbf{R}_{2000}$} & Prawn & $0.96 \pm 0.01$ & $39.8 \pm 0.4^{\mathrm{b}}$ & $78.6 \pm 0.9^{b}$ & $368 \pm 4^{\mathrm{d}}$ & \multirow{5}{*}{$1700 \pm 23$} & \multirow{5}{*}{$50068 \pm 1818^{c}$} \\
\hline & Rui & $20.1 \pm 0.1$ & $231.8 \pm 8.5^{\mathrm{c}}$ & $84.7 \pm 14$ & $353 \pm 17^{\mathrm{a}}$ & & \\
\hline & Catla & $20.5 \pm 0.1$ & $214.4 \pm 16.1$ & $8601 \pm 2.8$ & $164 \pm 10^{c}$ & & \\
\hline & Silver carp & $22.6 \pm 0.1$ & $580 \pm 4$ & $90.7 \pm 1.8$ & $755 \pm 17$ & & \\
\hline & Mola & $1.27 \pm 0.01$ & - & - & $61 \pm 3^{b}$ & & \\
\hline
\end{tabular}

Means with the different superscripts in same column are significantly different $(\mathrm{P}<0.05)$

\section{Discussion}

A number of water quality parameters such as temperature, transparency, $\mathrm{pH}$ and dissolved oxygen were monitored weekly. Total alkalinity, $\mathrm{NH}_{3}-\mathrm{N}, \mathrm{NO}_{2}-\mathrm{N}, \mathrm{NO}_{3}-\mathrm{N}, \mathrm{PO}_{4}-\mathrm{P}$, and chlorophyll-a were monitored fortnightly and fish growth was monitored at monthly interval. Significant variations $(\mathrm{P}<0.05)$ were observed for total alkalinity, $\mathrm{NH}_{3}-\mathrm{N}$ and chlorophyll-a among the treatments. Boyd and Zimmerman (2000) suggested the ideal ranges of water temperature as $28-32{ }^{\circ} \mathrm{C}$ for grow out phase of M. rosenbergii. Azim et al. (2004) observed water temperature ranged from 28 to 33.1 ${ }^{\circ} \mathrm{C}$ was suitable for tropical fish culture. Water temperature in the present study varied from $28-34^{\circ} \mathrm{C}$ with overall mean of $30.2{ }^{\circ} \mathrm{C}$ in all treatments, which was suitable for prawn and finfish culture. Secchi disk reading becomes lower when the abundance of phytoplankton increases into a water body and vice-versa. Secchi disk visibilities in fertilized ponds fluctuate over time and a transparency between 15 and $40 \mathrm{~cm}$ is good for fish culture (Boyd, 1982). In the present study, the water transparencies were found to vary from 25 to $46 \mathrm{~cm}$ in different treatments which were similar to the observations of Wahab et al. (1995) and Kohinoor (2000) in Bangladesh. Water pH less than 6.5 or more than 9 - 9.5 for long periods is harmful to reproduction and growth of fish (Mount 1973). According to Boyd and Zimmerman (2000) ideal range of $\mathrm{pH}$ for the grow-out phase of $M$. rosenbergii is 7. 8.5. Water $\mathrm{pH}$ in the different treatments of present study varied from 7.1 to 8.7 , in which only in a few instances $\mathrm{pH}$ values exceeded 9.0. Dissolved oxygen (DO) concentration at 9:00 to 10:00 hours ranged from $4.65-5.89 \mathrm{mg} \mathrm{l}^{-1}$ in different treatments throughout the study period with the mean values of nearly $5.8 \mathrm{mg} \mathrm{l}^{-1}$, which were within the ideal range $\left(3-7 \mathrm{mg} \mathrm{l}^{-1}\right)$ recommended by Boyd and Zimmerman (2000). Alkalinity below $30 \mathrm{mg} \mathrm{l}^{-1}$ limits primary production in well fertilized ponds (Boyd, 1990). In the present study alkalinity of pond water in all treatments were suitable for the primary production throughout the study period. Nitrogenous compounds such as nitrate, nitrite, phosphate and ammonia were within the recommended ranges for freshwater prawn culture (Boyd and Zimmerman, 2000).

The mean survival rate of prawn in the present study was significantly higher in treatment $\mathrm{R}_{0}(63.6 \pm 1.1 \%)$. The overall survival of prawn (50 to 64\%) in the present experiment was more or less similar to the reported values in earthen ponds: 62\% (Kumar et al., 2000), 52 to 55\% (Mazid and Mahmud, 1994) and 57 to 66\% (Uddin et al., 2006). 
The net production of prawn in the present study ranged between $361-540 \mathrm{~kg} \mathrm{ha}^{-1}$ which was higher than those reported by Haque et al. (2003) and Mia (2004). However, Kunda et al. (2008) found net production of freshwater prawn ranged from 268 to $570 \mathrm{~kg} \mathrm{ha}^{-1} 120$ days $^{-1}$ which is similar with the present study.

The harvesting weight of rohu was found 216 to $408 \mathrm{~g}$ which is more or less similar to Azim et al. (2001). Individual growth performance of rohu was better in $\mathrm{R}_{500}$ whereas, higher gross and net productions of this fish were resulted in the treatment $\mathrm{R}_{2000}$ (393 and $353 \mathrm{~kg} \mathrm{ha}^{-1}$, respectively) where stocking density of the species was higher. The combined gross and net production of finfish and prawns did not differed significantly $(\mathrm{P}<0.05)$ among the treatments. The net production of rohu was 180 to $372 \mathrm{~kg} \mathrm{~h}^{-1}$ in 172 days culture period. The net production of rohu varied due to different stocking densities in different treatments.

The harvesting weight of silver carp was found 564.89 to $626.29 \mathrm{~g}$ which is higher than Ahmed (2005) who found mean weight ranged from 189.9 to $280.35 \mathrm{~g}$. Final harvesting weight of catla ranged from 191.36 to $325.00 \mathrm{~g}$ which is comparable to Islam (2005) and Nahid (2006) who found average weight of catla ranged from 406.19 to $528.43,258$ to 364.40 and 224.72 to $330.34 \mathrm{~g}$. The production of mola in the present study (111to $142 \mathrm{~kg} \mathrm{ha}^{-1}$ ) was comparable to other reported values: 124 to $152 \mathrm{~kg} \mathrm{ha}^{-1} 120 \mathrm{~d}^{-1}$, stocked at a density of 20,000 ha ${ }^{-1}$ with freshwater prawn (Kunda et al., 2008), 52 to $84 \mathrm{~kg} \mathrm{ha}^{-1} 138 \mathrm{~d}^{-1}$, stocked at a density of 25,000 ha ${ }^{-1}$ with major carps (Kadir et al., 2006). The advantage of stocking mola in polyculture is that once stocked, no need of restocking because it breeds at least twice a year under natural conditions (Kohinoor, 2000). The combined net production of prawn and finfish ranged between 1696 to $1835 \mathrm{~kg} \mathrm{ha}^{-1} 172 \mathrm{~d}^{-1}$ which is higher than the findings of Asaduzzaman et al. (2006) who reported annual production of freshwater prawn was $412 \mathrm{~kg} \mathrm{ha}^{-1}$ in monoculture and $390 \mathrm{~kg} \mathrm{ha}^{-1}$ in polyculture with finfish $\left(660 \mathrm{~kg} \mathrm{ha}^{-1}\right)$ in the southeast region of Bangladesh. However, Kurup and Ranjeet (2002) reported that production from polyculture system ranged from 70 to $500 \mathrm{~kg} \mathrm{ha}^{-1}$ of freshwater prawn and 200 to $1200 \mathrm{~kg} \mathrm{ha}^{-1}$ of fish.

The net profits were $1,20,359,1,03,182,82,510,69,170$ and 50,068 (Tk. ha ${ }^{-1}$ crop $^{-1}$ ) in treatment $R_{0}, R_{500}, R_{1000}, R_{1500}$ and $R_{2000}$, respectively. The higher BCR was obtained in treatment $R_{0}(1.65)$ followed by $R_{500}(1.53), R_{1000}(1.42), R_{1500}$ (1.34) and $R_{2000}(1.24)$, respectively which indicate that rohu affect the economic return negatively.

\section{Conclusion}

Inclusion of rohu did not affect the growth and production of silver carp and mola, but catla production was adversely affected. Prawn survival, growth and production were decreased with increasing density of rohu. The overall production of prawn was higher in treatment $\mathrm{R}_{0}$, but combined production of prawn and finfish was better in treatment $\mathrm{R}_{500}$. Net profit derived from the experiment was high and equal in treatment $R_{0}$ and $R_{500}$. Therefore, inclusion of rohu at a density of $500 \mathrm{ha}^{-1}$ may be recommended for higher production and economic return in prawn-carp-mola polyculture system.

\section{Acknowledgements}

The author is honored to express his sincere appreciation to his supervisor Professor Dr. Md. Abdul Wahab, and Cosupervisor Professor Dr. Nesar Ahmed, Department of Fisheries Management, Bangladesh Agricultural University (BAU). He also acknowledges to DelPHE for funding in this research program.

\section{References}

[1] Ahmed, F. Effect of silver carp and bottom feeders on small indigenous species (SIS) and pond ecology. M.S. dissertation, Dept. of Fisheries Management, Bangladesh Agricultural University, Mymensingh, 2005; 80.

[2] Ahmed, K. Nutritional blindness in Bangladesh. In Touch: VHSS Newsletter No. 45(Feb): 1981; 1-2.

[3] Asaduzzaman, M., M.A. Salam, M.A. Wahab, M. Kunda and M.B. Rahman. Effects of control of C/N ratio by low-cost carbohydrate addition on water quality and pond ecology in freshwater prawn Macrobrachium rosenbergii post-larve nursing system. Bangladesh J. Fish. Res., 10(2), (2006) 121-130.

[4] Azim, ME., M.A. Wahab, A.H.M. Kamal, Z.F. Ahmad and M.C.J. Verdegem. Feeding relations of silver barb, Barbodes gonionotus (Bleeker) with Major Indian and common carp and its effect on fish production in a polyculture system. J. World Aquacult. Soc., 35 (2004) $100-108$.

[5] Boyd, C.E. Water Quality Management for Pond fish culture. Elsevier Science Publishers B.V., 1000 Amsterdam, the Netherlands, $1982 ; 318$.

[6] Boyd, C.E. Water Quality in Ponds for Aquaculture. Birmingham Publishing Co. Bermingham, Alabama, USA, $1990 ; 477$.

[7] Boyd, C and S. Zimmerman. Grow-out systems - water quality and soil management. In: New, M.B and W.C. Valenti (eds), Freshwater prawn culture. Blackwell Science, Oxford, UK, 2000; 221-238.

[8] Cohen, D. and Z. Ra'anan. The production of freshwater prawn Macrobrachium rosenbergii in Israel. III. Density effect of all-male Tilapia hybrids on prawn yield characters in polyculture. Aquaculture, 35: (1983) 57-71. 
[9] Haque, M.M., N.R. Narejo, M.A. Salam, S.M. Rahmatullah and M.A. Islam. Determination of optimum stocking density of Macrobrachium rosenbergii in carp polyculture in earthen pond. Pak. J. Biol. Sci., 16: (2003) 898-901.

[10] Islam, M.S. Optimization of stocking density of freshwater prawn, Macrobrachium rosenbergii with carp polyculture in ponds. M.S. dissertation, Dept. of Aquaculture, Bangladesh Agricultural University, Mymensingh (2005) 69

[11] Kadir, M.A., S.R. Kundu, A. Milstein and M.A. Wahab. Effects of silver carp and small indigenous species on pond ecology and carp polyculture in Bangladesh. Aquaculture, 261 (2006) 1065-1076.

[12] Kohinoor, A.H.M. Development of culture technology of three small indigenous fish-mola (Amblypharyngodon mola), punti (Puntius sophore) and chela (Chela cachius) with notes on some aspects of their biology. Ph.D. dissertation, Dept. of Fisheries Management, Bangladesh Agricultural University, Mymensingh, (2000) 363.

[13] Kumar, J.S.S., N. Nagamuthu, S. Velliah, N. Nagarathinam and V. Sundararaj. Production characteristics of Macrobrachium rosenbergii and M. malcomsonii under controlled monoculture system. Journal of J. Aquacult. Trop., 15 (2000) 121-126.

[14] Kunda. M., M.E. Azim, M.A. Wahab, M.A. Majid, S. Dewan and S.H. Thilsted. Performance of Tilapia (Oreochromis niloticus) and Catla (Catla catla) with Prawn (Macrobrachium rosenbergii) and Mola (Amblypharyngodon mola) in Alternate Method of Rice-fish Culture Systems. Aquatic Sciencec (2008).

[15] Kurup, B. M. and K. Ranjeet. Integration of Freshwater Prawn culture with rice farming in Kuttand, India. Naga, 25 (2002) $16-19$.

[16] Ling, S.W. Method of rearing and culturing Macrobrachium rosenbergii (De Man). FAO Fisheries Report, 5(3) (1969) 589-19.

[17] Mazid, M.A. and Y. Mahmood. Growth performance of giant freshwater prawn Macrobrachium rosenbergii in monoculture in ponds with supplemental feed. In: Chou, L.M., A.D. Munro, T.J. Lam, T.W. Chen, L.K.K. Cheong, J.k. Ding, K.K. Hooi, V.P.E. Phang, K.F. Shim and C.H. Tan (eds), Proceedings of the Third Asian Fisheries Forum: Asian Fisheries Society, Manila, Philippine (1994) 1010-1012.

[18] Mia, M.Y. Cultivation of prawn in polyculture with some species of Indian and Chinese carps. Pak. J. Sci. Indust. Res., 47(2) (2004) 107-111.

[19] Mount D.I. Chronic effect of low pH on fathead minnow survival, growth and reproduction. Water Res., 7 (1973) $987-993$.

[20] Nahid, S.A. Culture sustainability of mola (Amblypharyngodon mola) with carp polyculture in farmesrs' ponds of Northern region of Bangladesh. M.S. dissertation, Dept. of Fisheries Management, Bangladesh Agricultural University, Mymensingh (2006) 73.

[21] Thilsted, S.H., N. Roos, and N. Hasan. The role of indigenous fish species in food and nutrition security in Bangladesh. NAGA News Letter, July-December (Supplement) 20 (1997) 13.

[22] Uddin, M.S. M.E. Azim, M.A. Wahab and M.C.J. Verdegem. The potential of mixed culture of genetically improved farmed tilapia (Oreochromis niloticus) and freshwater prawn (Macrobrachium rosenbergii) in periphyton-bsaed systems. Aquaculture Research, 37 (2006) 241-247.

[23] Wahab, M.A., Z.F. Ahmed, M.A. Islam and S.M. Rahmatullah. Effect of introduction of common carp, Cyprinus carpio (L) on the pond ecology and growth of fish in polyculture. Aquaculture Research, 26 (1995) 619-628.

[24] Wahab, M.A., and Z.F Ahmed. Effects of planktivorous carps species combination on food organisms and electivity indices in the fish ponds. Progress. Agric., 2(2) (1991) 21-30.

[25] Zafri, A. and K. Ahmed. Studies on the vitamin-a content of fresh water fishes, content and distribution of vitamin-An in mola (Amblypharyngodon mola) and dhela (Rohtee cotio). Bangladesh J. Bio. Sci. (1981) 10: 47-53.

[26] Zimmermann, S. and M.B. New. Growout systems-Polyculture and Integrated culture. In: New, M.B. and W.C. Valenti (eds), Freshwater Prawn Culture: The farming of Macrobrachium rosenbergii. Blackwell Science Ltd., UK, 2000; 187-202. 